\title{
Editorial
}

\section{Before and after Liver Transplantation}

Advanced stage liver disease represents a serious problem worldwide in terms of morbidity and mortality, being the principal indication for liver transplantation too.

All around the world, several transplant centres are involved in a complex medical and surgical management of the candidates for liver transplantation. In Italy too, this is a consolidated practice, even if affected by the shortage of donors and available organs to be transplanted. The education about the importance of the donation and a better clinicians' awareness of the procedures, the risks and the benefits of liver transplantation, will improve the administration of this precious health resource.

The clinical management of patients awaiting liver transplantation and the correct treatment of the complications occurring after the transplant, or of the recurrence of the original liver disease, must be considered as the principal matters in the liver transplant setting.

This special issue is focused on the analysis of some "hot topics" about clinical matters that we consider essential to be known by both surgeons and clinicians, presenting before or after liver transplantation.

Annicchiarico B.E. et al. in the article "Pegylated interferon and ribavirin for chronic hepatits $\mathrm{C}$ virus infection in decompensated cirrhotics awaiting liver transplantation" considers the problem of the antiviral treatment in such delicate patients as those in waiting list, often at high risk of worsening of liver function.

Ponziani F.R. et al. in the article "Walking on the molecular pathway: m-TOR inhibition in the transplant setting" examines an innovative argument which rises a great interest in the transplant literature: the use of m-TOR inhibitor as both immunosuppressive and anti cancer drugs.

Pompili M. et al. in the article "Bridge treatments for HCC in the waiting list for liver transplantation" deals with one of the most important topics in the management of patients in waiting list affected by hepatocellular carcinoma: the high risk of disease progression and, thus, the need of a treatment to keep a stable disease.

Avolio A.W. et al. in the article "The predictive power of donor risk index and MEDL score. An analysis of the OPTN database" analyzes the actual debate regarding the donor-recipient matching and its possible implications for the transplant outcome.

Garcovich M. et al. in the article: "Monitoring haemostasis during and after liver transplantation" examines the great matter of the intraoperatory management of patients' with a reduced coagulative capacity, such as recipients with chronic liver disease, and what the clinician has to expect after liver transplantation about it. 
Finally, Milani A. et al. in the article "Current status of liver and multiple organ transplantation" analyzes the features of combined organ transplantation and the recent literature evidences.

Editors thank the reviewers of the papers presented in this issue: Dr. Maria Assunta Zocco, Dr. Francesco Franceschi, Dr. Veronica Ojetti, Dr. Franco Scaldaferri and Dr. Cristiano Lauritano.

Antonio Gasbarrini and Francesca R. Ponziani (Guest Editors)

Catholic University of Rome

Largo A. Gemelli 8 00168 Rome Italy

E-mail: agasbarrini@rm.unicatt.it E-mail: francesca.ponziani@yahoo.it

(C) Gasbarrini and Ponziani; Licensee Bentham Open.

This is an open access article licensed under the terms of the Creative Commons Attribution Non-Commercial License (http://creativecommons.org/ licenses/by-nc/3.0/), which permits unrestricted, non-commercial use, distribution and reproduction in any medium, provided the work is properly cited. 